の硫酸イオン錯体の全生成定数として， $\log \beta_{1}=0.61, \log$ $\beta_{2}=1.65, \mathrm{Zn}$ の硫酸イオン錯体の全生成尘数として， $\log$ $\beta_{1}=0.53, \log \beta_{2}=1.19$ を得た，をた，金嘱錯体の生成定

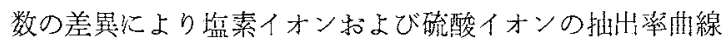
に与无る影劉が異なり，これによって金属の分離が容易と なる，本研究では证素イオンの标在する条件のもとで， Cd と Zn の分離が容易になることが明らかになった。さ

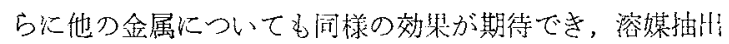

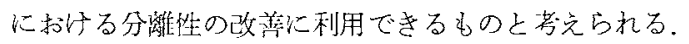

\section{文献}

(1) A.W.Fletcher and D.S.Flett : Solvent Extraction Chemistry of Metals, Macmillan, London, (1965), 359.

(2) G.H.Morrison and H.Freiser : Solvent Extraction in Analytical Chemistry, Wiley, New York, (1957), 145.
（3）斎藤敏男，四辺晃至，西村山治，近藤良夫：日本鉣 業会誌，88(1972)，215。

（4）村山勝男：日本鈗業会誌，85(1969)，187.

(5) A.W.Fletcher and D.S.Flett : J.App1. Chem., 14 (1964), 215.

(6) I.Prigoine and R.Defay:化学熱力学(妹毛学計),

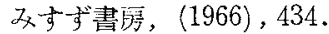

(7) G.K.Schweitzer and F.C.Clifford : Anal.Chim. Acta., $47(1969), 57$.

(8) P.W.Cassidy and A.R.Burkin : Int. Conf. on Solvent Extraction, The Hague, (1971), 476.

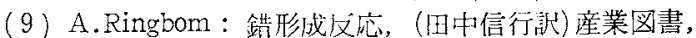
(1965), 272.

(10) I.Leden : Acta.Chem.Scand., 6(1952), 971.

(11) P.K.Jena and B.Prasad : J.Indian.Chem.Soc., 39 (1962), 33 .

(12) D.S.Flett : Solvent Extraction Chemistry, North Holland, Amsterdam, (1967), 60.

(13) F.J.C.Rossotti and H.Rossotti : J.Phys.Chem., 63 (1959), 1041.

(14) J.Kenttämaa : Acta Chem.Scanđ., 12(1958), 1323.

\title{
非強磁性 $\mathrm{Cr}-\mathrm{Co}$ 稀薄 2 元合金のインバー・エリンバー特性*
}

\section{深道和明** 福田憲男 ${ }^{* * *}$ 斎藤英夫**}

Kazuaki Fukamichi, Norio Fukuda and Hideo Saito : Invar and Elinvar Characteristics in Nonferromagnetic $\mathrm{Cr}-\mathrm{Co}_{0}$ Dilute Binary Alloys. Invar and Elinvar alloys are important materials for precision instruments. But, practical applications of these alloys are often restricted because of their ferromagnetism. Therefore, researches to develop nonferromagnetic Invar or Elinvar alloys have recently received considerable attention.

Chromium is an antiferromagnetic metal and its physical properties around the Néel temperature are drasticaliy affected by the addition of solute atoms. We have investigated the thermal expansivity $\Delta l / l$, the electical resistivity $\Delta \rho / \rho$ and the temperature dependence of magnetic susceptibility $\chi$ for $\mathrm{Cr}$-Co dilute alloys. The thermal expansivity of these alloys in the vicinity of room temperature is very small, showing the Invar characteristics. Some alloys show also the Elinvar characteristics in the same temperature range where the Invar characteristics occur. It is for the first time that both Invar and Elinvar characteristics have been found in chromium dilute binary alloys. The magnetic susceptibility of these alloys is less than $5 \times 10^{-6} \mathrm{emu} / \mathrm{g}$, indicating that these alloys are practically nonferromagnetic.

In these alloys the Néel temperature varies irregularly with increasing cobalt concentration; it decreases slightly for cobalt concentrations up to $2.0 \% \mathrm{Co}$, increases up to $2.5 \% \mathrm{Co}$, and decreases with further increase in cobalt concentration. But the Néel temperature determined from the temperature dependence of $\Delta \rho / \rho$ and $\chi$ does not coincide with an inflection point on the thermal expansivity curve.

(Received November 24, 1973)

\section{I. 緒言}

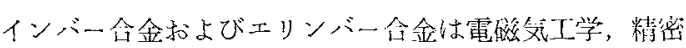
計測工学の分野で㕕く利用されている。しかし，従来実用 に供されているこれらの全金はすべて強磁性であり，その
强䣲珄がしばしば応用上の障些となる。

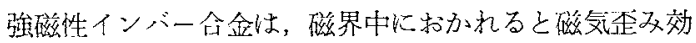

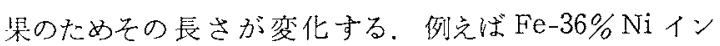
バー全金虫 $800 \mathrm{e}$ の磁場のもとで，単位長さ当り $2 \times 10^{-5}$

***東北大学金属材料研究所 (The Research Institute for Iron, Steel and Other Metals, Tohoku University, Sendai)

*** 東北大学大学浣 (Graduate School, Tohoku University, Sendai)

* 1973 年 4 月金属学会東京大会比一部発表 
以上，すなわち $1^{\circ} \mathrm{C}$ の温度変化に上る熱膨張以上も磁場 万向に伸びるため(1)精密計測，電磁気材料としての役割を

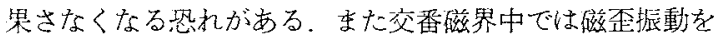
おこすため不適当である。さらに強磁性エリンバー合金 は，磁界中におか机ると $\Delta E ，$ または $\Delta G$ 効果により弾性 特性が著しい影製を受忛る。たとえば，Fe-Ni-Cr 系エリ ンバー全金は $252 \mathrm{Oe}$ の酳界中では变ったくエリンバー特 性を失う(2)，侍計のひげぜんまいにもェりンバー合金が使 われているため，磁界中では歩度変化を生じ 80 oe では㭙 計は停止してしまう ${ }^{(3)}$.

以上のような理由により，非強磁性(すなわち不感磁性) のインバーおよびェリンバー合金の研究開発が久しく待望 されていた。

ところで，弾珄特性は結旨学的異方性が著しいため，多 絬琩体では加工率や熱処理などにより比較的容易にェリン ベー特性が得られる。したがって非強磁性のェリンバー特 性は常磁性金属・合金や反強磁性合金に打いてしばしば見

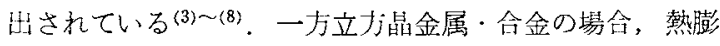
誩には弾性定数のような絬晶学的異方性がないから，強磁 性を避けてインバー特性を得ようとすれば反強磁性の出現 に伴ら異常体積効果によるほかはないであうら。Mnを主 成分とする $\mathrm{Mn}-\mathrm{Cu}, \mathrm{Mn}-\mathrm{Ni}$ 合金などの反強磁性合金で は，組成によっては室温付近でマルテンサイト変態および 磁気変態をおこし，熱膨張係数が小さくなる温度領域が存 在するが(9)，その不可逆性のため実用的な意義は汪とえぞ ない，その他 $\mathrm{Mn}$ 采反強磁性合金は非強磁性エリンバ一合 金にも見られるとおり，一般汇熱膨張係数が大きく(6)，こ れまでに得られた最小の熱膨張係数 $\alpha て ゙ も \mathrm{Fe}-34.8 \% \mathrm{Mn}$ 合金の約 $8 \times 10^{-6}$ であり (10)，インバー合金としては利用 できない、インバー合金としては少なくとも $\alpha$ は $4 \times 10^{-6}$ 以下の值が要求される.

ところで, Cr 基 1 次固溶体合金の物理的諸性䓄は先ず， Newmann 等により $\mathrm{Cr}-\mathrm{Fe}$ 系について研究され(11)，熱影 張や電気抵抗がネール温度付近で著しく変化することが見 出された。 その後，Overhauserによりバンドモデルに基 つくスピン缺度波 (Spin Density Wave)の理論が提唱さ $れ^{(12) ， 1}$ 次固溶体合金の研究が純 Cr の研究之共に数多く 行なわれている(13)〜(20). $\mathrm{Cr}-\mathrm{V}^{(13)}, \mathrm{Cr}-\mathrm{Fe}^{(14)}, \mathrm{Cr}-\mathrm{Mn}^{(13)}$ 系 などでは中性子胹折の実䮦から磁気的相図 (Magnetic Phase Diagram) \&作成されていて，添加元素の種類また は温度変化により磁気構造が多様に变化し，それに伴って 熱膨張，弾性定数，電気抵抗などに筫常が現われる。著者 らはこれらの点に着目して研究した結桨すでに，Cr-Fe$\mathrm{Mn}, \mathrm{Cr}-\mathrm{Fe}-\mathrm{Ru}$ や $\mathrm{Cr}-\mathrm{Fe}-\mathrm{Sn}$ などの $\mathrm{Cr}-\mathrm{Fe}$ 系 3 光 1 次固 溶体のインバー合金を多数見出した ${ }^{(21) \sim(24) .}$

ところで Cr-Co 1 次固溶体合金に和いても邆移温度付近 で著しい体積変化が生ずることが知られているので(25)，

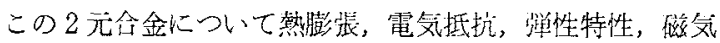

的性質などを研究した結果，非强磁性のインバー合金でか つエリンバー特佬をる共有する合金が得られたので報告 する。

\section{II. 実 験 方 法}

純度 $99.99 \%$ の Cr z $99.9 \%$ Co を用い，アルゴン雾囲 気中で最初ボタン状に 3 回アーク溶解を繰り这し,さらに 測定試料としての成形を容易にするために，同じくアルジ ン雲围気中でアーク溶解して短冊状合金を作った。このよ らにして作製された全金を石英管に真空封入して， $800^{\circ} \mathrm{C}$ で3日䦓均一化熍鈍した後炉冷した。 それ角棒状に切り 出し，再び $800^{\circ} \mathrm{C} て ゙ 24$ 時間焼鈍した後炣冷したものを試 料とし，電気抵抗や熱膨張などの測定に供した。

電気抵抗の温度依存性は直流電位差計を用い四端子法に よって求めた。

熱膨張率の温度依存性はローラー・ミラー法による熱膨 張湘定装置に上って求めた。

禾た磁化率の温度依存性ならびた磁化曲線は磁気天科に よって求めた。

さらに固有振動数の濫度依存性の測定は静電駆動方式に よって行なった。

\section{III. 結果および考察}

Fig. 1 K Cr-Co 2 元 1 次固溶体合金の熱膨張曲線を示 す。室温付近では, 初めCo 量が增加するにつれ熱膨張率 $\Delta l / l$ は小さくなる．特に $\mathrm{Cr}-2.12 \% \mathrm{Co}$ 合金では－10３0 ${ }^{\circ} \mathrm{C}$ 付近において， $\Delta l / l$ ははとんど变化はず熱膨張係数 $\alpha$

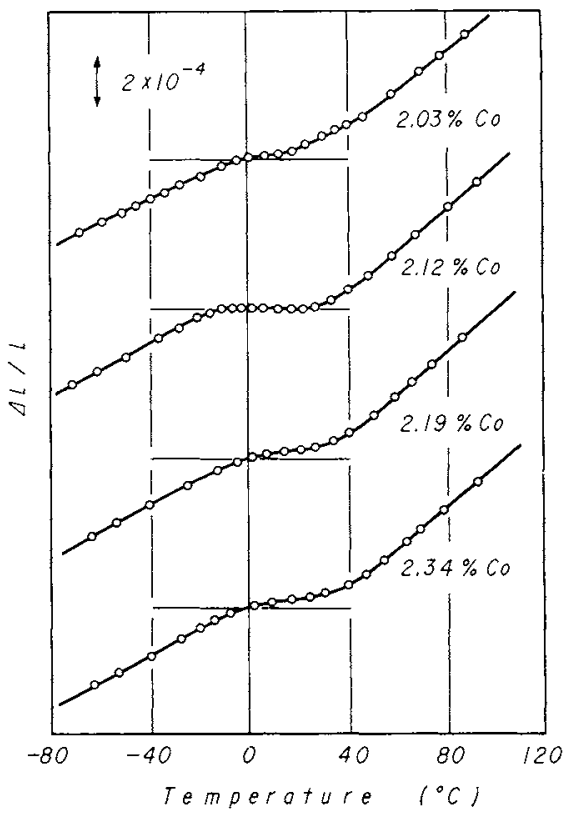

Fig.1 Temperature dependence of the thermal expansivity for some $\mathrm{Cr}$-Co alloys. 
はほとんど 0 であり，非常に優れたインバー特性が得られ る.

さらにCo 量が堌加するにつれ $1 / /$ は逆にだんだん 大きくなるが，3.44\% Co 合金でも室滥付近での $\alpha$ は約 $3.5 \times 10^{-6}$ で普通の金属合金の数分の 1 でありインバー特 性を有することがわかる。な技，高温側においては熱膨張 率はぞの合金の場合も純 Cr のそれと大体同じである。

これまでに報告した Cr 基 1 次固溶体合金のインバー特 性は，すべて Cr-Fe含金の著しい $\Delta l / l$ の变化に着目し， $\mathrm{Mn}, \mathrm{Sn}, \mathrm{Ru}$ などの第 3 元素を添加し， $\Delta l / l$ とネール温度 を制御した 3 元合金で得られたものである。ところが本研 究に上り $\mathrm{Cr}$ の 2 元 1 次固溶体合金に执いてもインバー特 性が得られることが明らかになった。しかし， Cr-Fe-Mn 合金などに较べるとインバー特性を示高温度領域はやや狄 い. 但し，第 3 元素を添加し， $\Delta l / l$ とネ一几温度を制御 することによっての領域を広くすることができる(26).

ところで，従来実用に供されているインバー合金の熱膨 張倸数が最小纪なる組成では, 弾性定数 $E$ の温度係数 $e$ の 絶対值が鼠大となる。したがって同一組成の合金でイン バー特性とェリンバー特性を同一温度で同特に示するのは ない。

Fig. 2 k Cr-Co 系合金の固有振動数 $f$ の温度变化を示 す。図に見られると扣り $\mathrm{Cr}-2.7 \% \mathrm{Co}$ 合金は $-20 \sim 20^{\circ} \mathrm{C}$ 付近で $\Delta f / f$ の変化が小さくエリンバ一特性を有すること がわかる。亦た前述のとおりこの合金はインバー特性も有 するから，Cr-Co 2 元合金でも適当炕組成を選べば $\mathrm{Cr}-\mathrm{Fe}$ $\mathrm{Mn}$ などの $\mathrm{Cr}$ 基 3 元 1 次固溶体合金子同様に，インバー， エリンバーの双方の特性を共有させることができる。この ことは精密計測機器の設計上，さらには測定精度の向上に 大切な要素となる。この双方の特性を闰一温度領域で共有

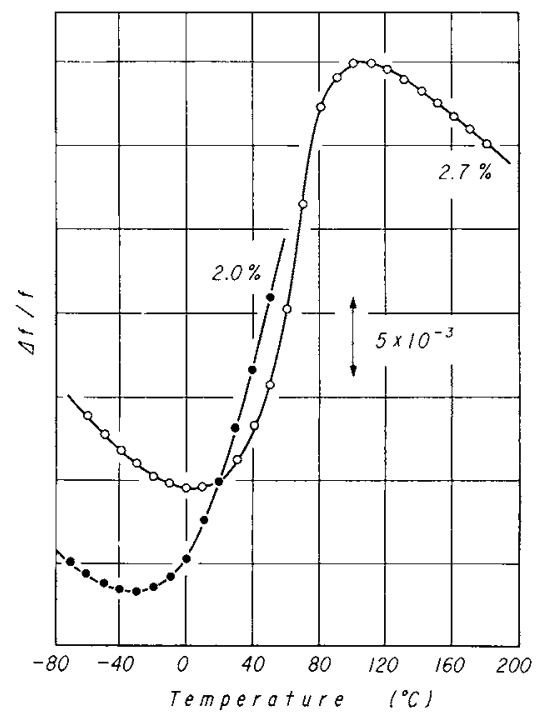

Fig.2 Fractional change of frequency of proper vibration for $\mathrm{Cr}$-Co alloys.
する合金は， $\mathrm{Cr}$ 基 2 元 1 次固溶体合金では，この $\mathrm{Cr}-\mathrm{Co}$ 采 で初めて見出された。 また $\mathrm{Cr}-2.0 \% \mathrm{Co}$ 合金では $-30^{\circ} \mathrm{C}$ 付近でもが小さくなるが，MnやRuなどのようにネール 温度を上昇させる第 3 元素を添加すると，丁度室温付近で エリンバー特性が得られる可能性があり，すで良好な特 性を示す合金系も見出しており近く発表の予定である(26).

Fig.3 にこれら合金の磁場 4000 Oe での磁化率 $\chi$ の温度

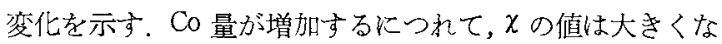
り，そのピーク值も増大する。しかしながら，これらとの 值は $\mathrm{Cr}-2.03 \% \mathrm{Co}$ 合金でも高々 $4.6 \times 10^{-6} \mathrm{emu} / \mathrm{g}$ にすぎ ず，実用上ほとんど無視できる程小さい，したがって上述 の合金は不感磁性のインバー・エリンバー合金と言い得 る.

Fig .4 に Cr-2.12\% Co 合金の磁化曲線を示す．曲線は わずかに上に凸であり，これと類似した現象は $\mathrm{Cr}-\mathrm{Fe} \mathrm{e}^{(27) ，}$ $\mathrm{Cr}-\mathrm{Fe}-\mathrm{Sn} \mathrm{n}^{(24)}$ 反強磁性合金沈小ても見出されている。こ の合金も超反強磁性 (Super Antiferromagnetism)を示す のかも知孔ない。しかし磁化 $\sigma$ の值は磁場によって急激に 変化することはないから実用上は問題とならない，

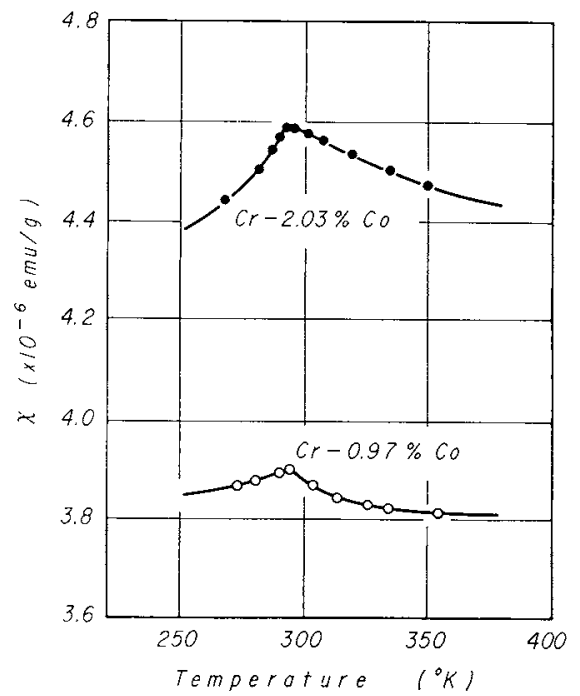

Fig.3 Temperature dependence of the magnetic susceptibility for $\mathrm{Cr}-\mathrm{Co}$ alloys.

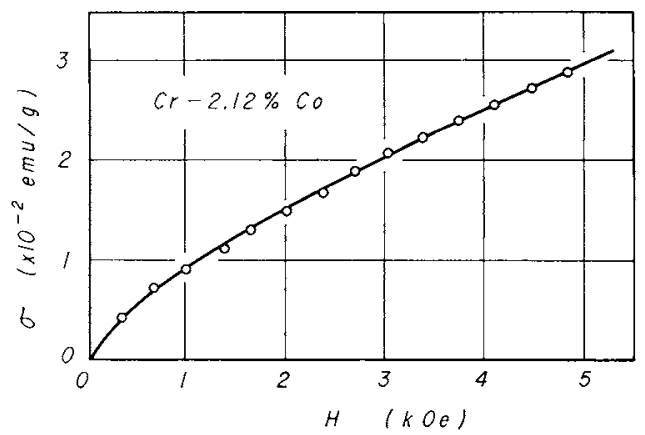

Fig.4 Magnetization curve of $\mathrm{Cr}-2.12 \% \mathrm{Co}$ alloy at room temperature. 
ところでスピン密度没を有する $\mathrm{Cr}$ 抢よび $\mathrm{Cr}$ 基 I次固 溶体合金や希土類金属に扔いては, 反強磁性が壮現するこ とによりフェルミ面の一部が臷断される結喿，ネール温度 でキャリアーの数が变化し電気抵抗が極小值 $\rho_{\min }$ 取る ことが知られている，厳密には遼移温度付近での輸送現象 に異常があるため， $\rho_{\min }$ は磁気モーメントが消失する滥 度，あるいは比熱の異常が扣こる温度から求めたネー儿灄 度よりも約 $1^{\circ} \mathrm{K}$ 高温側にずれるが(28)，一般に Cr 基 1 次 固溶体合金のネール温度付近での電気抵抗の変化が顕著で 西るため， $\rho_{\min }$ からネール温度が決定される場合が多い。

Fig. 5 に $\Delta \rho / \rho$ の温度依存性を示寸。いずれの組成の合 金においても明瞭な極小が存在し，Co 量が增加するにつ れて一層明暌になってくるので，この合金でも電気抵抗の 測定からネール温度が容易に決定できる。

Fig.6に上述の方法に上って求めたネール温度の組成低 栐性を他の研究者の結果と比較して示吉(29) (31).

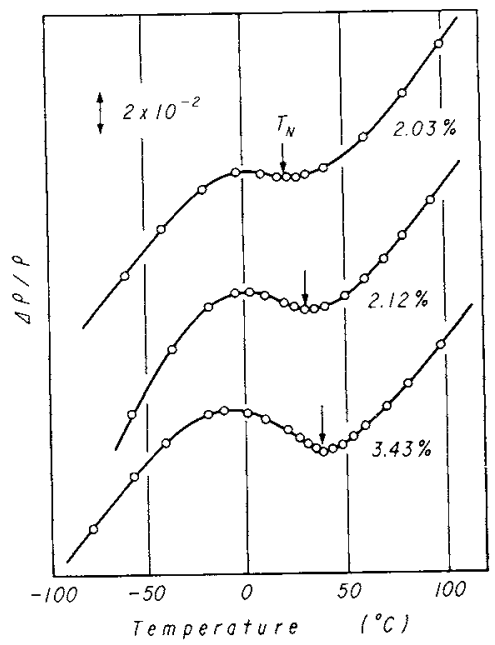

Fig.5 Temperature dependence of the electrical resistivity for some $\mathrm{Cr}$-Co alloys.

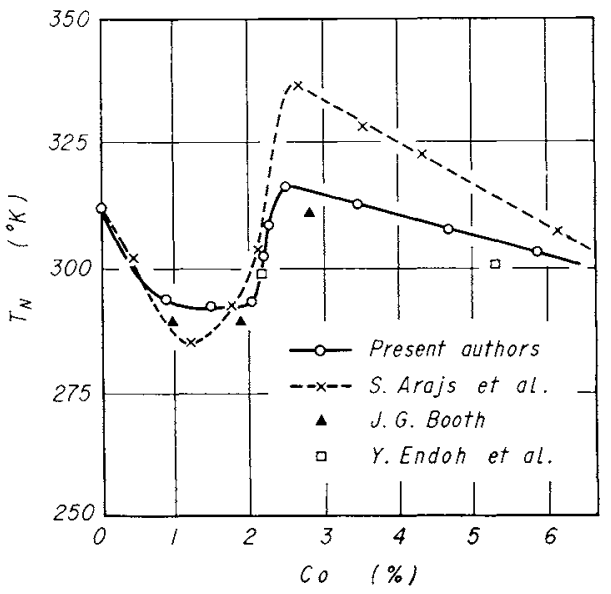

Fig.6 The Néel temperature of $\mathrm{Cr}-\mathrm{Co}$ alloys as a function of $\mathrm{Co}$ concentration.
一般に Mn，Ru，Osなどのように周期律表上で Crより 右側にある遷移金属元素を添加するとネール温度は上并 乙，逆にW，Nb，Tiなどを添加卞ると降下する(32)〜(35). ところが強磁性元素である $\mathrm{Fe}, \mathrm{Co}, \mathrm{Ni}$ を添加した場合, これらの元素がいずれる周期律表上でCrより右側にある にもかかわらず異常な変化を示す。すおわち，FeやNiの 添加の場合はネール温度は直線的儿降下し，Co 添加の場 合は不规則な変化を示し，Co の添加と共に初めネール温 度は降下し，約 2～2.5\%の簌囲で急激に上舅し，その後， 再び緩やか沉降下する。この約 $2 \%$ 付近の急激な变化はス ピソ構造がスピン密度波の横波(Transverse Sinusodial Spin Density Wave)から普通の单純な反磁強性(Commensurable Antiferromagnetism) 江変化し，安定化される絬 果，ネール温度が上昇するものと考光られている(31)，なお 図の結果は研究者により多少の差異が譛められるが，著者 らは $800,900,1100^{\circ} \mathrm{C}$ の各々の温度で熱処理してもネー ル温度には変動がないことを確認した。したがってこの差 異は熱処理条件により生じたものではないと考兄られる。

ところで熱力学でよく知られているよらに相変態が，第 I種あるいは第 2 種のいずれであっても変態温度において 体積変化の買常が生ずる，すなわち，第 1 種の変態ては体 種の不連続変化を㧍こし，第2 種の変態ならば熱膨張倸数 が不連続になる、したがって $4 l / l$ の濫度依存性からも磁 気变態温度が決定でき，従来 $\mathrm{Cr}$ 基合金炕おいてもしばし ぱこの方法でネール温度が決是されている(14)(31).

しかし，Fig.7 に示すように Cr-0.97\% Co 合金の場合， 磁化率 $\chi か ゙$ 極大を示寸温度と $\Delta \rho / \rho$ が極小となる温度とは 大体一致するが， $\Delta l / l か ゙$ 急激に变化する温度は一致しな

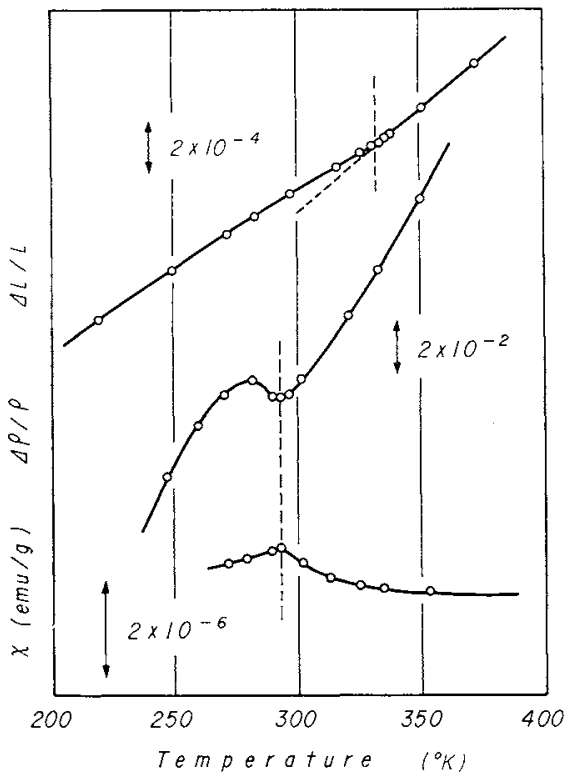

Fig.7 Temperature dependence of thermal expansivity, electrical resistivity and magnetic susceptibility for $\mathrm{Cr}-0.97 \% \mathrm{Co}$ alloy. 
い、この現象は本実験のすべての組成の合金に見られる。 なお， $A l / l$ の温度変化仙可逆的であり， $\Delta l / l$ が急激に変

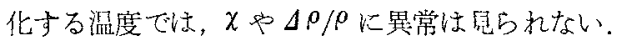

加工に上る残留歪文があるときCr のネール温度は上昇 し，艺のスピン構造も变化することが知られているが(36)， Cr 基 1 次固溶体合金炕批いても，その上らな问能性がみ る。事实，Cr-0.97\% Co 合金の場合，維粒状化砕いたま まの状態て磁化率を測定すると，極大の位置はFig.3に示

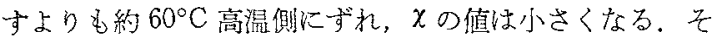
れ故，本実駼汇执いてはこの点に留意し，同一条件の同一 試料を用いて $\Delta l / l, \Delta \rho / \rho ， \chi$ の温度依存性を求めた。した がって，Fig.7に見ら礼る選移温度の一致しない原因を試 料作製上の問題に帰することはできないであろう。

これに類似した現象は $\mathrm{Cr}-\mathrm{Ni}^{(31)}, \mathrm{Fe}-\mathrm{Mn}^{(37)}$ 反強磁性合 金でも見出さ礼ている。 $\mathrm{Cr}-\mathrm{Ni}$ 合金の埸合，熱膨膂率から 求めた遷移温度の方が，中性子回折の実絤から求めた遥移 温度よりも約 $10^{\circ}$ 高い。また， $\mathrm{Fe}-\mathrm{Mn}$ 合金の場合，比熱

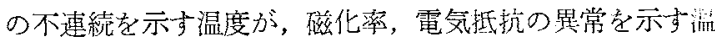
度よりも約 $10^{\circ} \sim 20^{\circ}$ 低い。

上述の異常現象は，Cr 基合金の場令， $\mathrm{Cr}-\mathrm{Co}, \mathrm{Cr}-\mathrm{Ni}$ 合 金だけ汇限られるのか，それとも非強磁性覆移金属元素起 添加した場合毛現われるのか現在多数の合金系について実 験中である。

\section{IV. 䋨論}

(1) Cr-Co 2 元 1 次固溶体全金においても室温付近で シバー特性が得られる。このような特性が Cr 基 2 元合金 で得られたのは本合金系が初めてである。委たこり合金の 磁性の影響は実用上完全に無視されれ街る。

(2) 室温付近でもェリンバー特性が得られる合金もあ る.したがってこの合金系はインバー，ニリンバーの特性 を共有することが明らかになった。このことは，精密計測 上重要なことである。

(3) $\Delta \rho / \rho$ および $\chi$ の温度依存性から求めたネール温度 そ $\Delta l / l$ の温度依存性から求めた折点温度々は一致しない。 同じよらな現象は他の二，三の命金系においても見出され ている.

(4) $\Delta \rho / \rho$ および $\chi$ の温度低存性から求めたネ一ル温度 の組成依存性はCo が Cr 上り周期律表上で右側にあるに もかかわらずネール温度を降下させ，しかも他の強磁性元: 素, $\mathrm{Fe}, \mathrm{Ni}$ 添加の場合と異なり，変化は不䙺則で亦る。

（5）純Crの唔合之同様，試料の残留歪友により，磁気 的性質は敏感に影響を受け，ネール濫度が高温㑯に移行 し，义の值は小さくなる.

終りに臨み，本研究に执いて，試料作製に当たられた東北 大学金属材料研究所の山田 務氏，拉よび試料の分析に当 たられた同研究所の共通分析の方々に謝意を表わします。

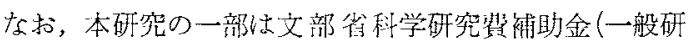
究B)の援助の子と行なわれたるのである。

\section{文献}

(1) A.Schulze : Z.Physik, 50(1928), 448.

(2) G.I.Katayev : Phys.Met.and Metallog., 11 (1961), No. 3,53 .

(3) S.Steinemann and M.Peter : Soc. Swisse. Chronom., (1968), No. $1 / 2,1$.

(4) H.Albert, F.Assmus and I.Pfeiffer : Solid State Comm., 4 (1966) , 519 .

（5）增本 量, 沢谷昭八：金属学会誌，33(1969)，121.

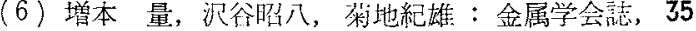
(1971), 723.

（7）堌本 量, 沢谷炤八，菊地紀雄：金属学会誌， 35 (1971) , 1143.

（8）增本 量，沢谷昭八，菊地紀雄：金属学会䋨，35 (1971), 1150.

(9) 深道和明, 斎藤英夫: 林発表.

(10) f斗治雍典, 白川勇記：金属学全誌，34(1970)，897.

(11) M.M. Newmann and K.W.H. Stevens : Proc. Phys.Soc., 74 (1959), 290.

(12) A.W.Overhauser : Phys.Rev.Lett., 4(1960), 462.

(13) T.J.Bastow : Proc.Phys.Soc., 88 (1966), 935.

(14) Y.Ishikawa, S.Hoshino and Y.Endoh : J.Phys. Soc.Japan, 22 (1967), 1221.

(15) S.Komura, Y.Hamaguchi and N.Kunitomi : J. Phys.Soc. Japan, 23 (1967), 171.

(15) H.Ohno, T.Suzuki and H.Takaki : J.Phys.Soc. Japan, $23(1967), 251$.

(16) Y.Hamaguchi and N.Kunitomi : J.Phys. Soc. Japan, $19(1964), 1849$

(17) M.A.Mitchell and J.F.Goff : Phys. Rev. B, 5 (1972), 1163.

(18) I.R.Herbert, P.E.Clark and V.H.Wilson : J. Phys.Chem.Solids, 33(1972), 979.

(19) A.Arrott, S.A.Werner and H.Kendrick : Phys. Rev., 153(1967), 624.

(20) S.Arajs and G.R.Dunmyer : J.Appl. Phys., 38 (1967), 1892.

(21) K.Fukamichi and H.Saito: Phys.Status Solidi (a), 10(1972), K 129 .

（22）斎藤英夫，深道和明：園体物理，7(1972)，411。

(23) H.Saito and K.Fukamichi : IEEE, Trans. Mag., 8 (1972), 687.

(24) 深道和明，鈴水雄一，斎藤英夫：金属学会誌，37 (1973), 927.

(25) T.Suzuki : J.Phys.Soc.Japan, 21 (1966) , 442.

（26）深道和明，福田憲男，斎藤英夫：投稿準供中。

(27) Y.Ishikawa, R.Tournier and J.Filippi : J.Phys. Chem.Solids., 26(1965), 1727.

(28) G.T.Meaden, K.V.Rao and H.Y.Loo: Phys.Rev. Lett., 23 (1969) , 475.

(29) S.Arajs, G.R.Dumyer and S.J.Dechter: Phys Rev., 154(1967), 448.

(30) J.G.Booth : J.Phys.Chem. Solids, 27 (1966), 1639.

(31) Y.Endoh, Y.Ishikawa and H.Ohno : J.Phys.Soc. Japan, 24 (1968), 263.

(32) A.K.Butylenko and V.N.Gridnev : Fiz. Metal. Metalloved, 19(1965) , 205.

(33) J.G.Booth : Phys.Status Solidi, 7(1964), K 157.

(34) B.Lebech and K.Mikke : J.Phys. Chem. Solids, $33(1972), 1651$.

(35) S.Arajs, E.Anderson and K.V.Rao : J.Less-Common Metals, $26(1972), 157$.

(36) G.E.Bacon and N.Cowlan : J.Phys.C, 2(1969), 238

（37）遠藤康夫，石涖義和：固体物理，5(1970)，316. 